\title{
Microalgal composition and primary production in Arctic sea ice: a seasonal study from Kobbefjord (Kangerluarsunnguaq), West Greenland
}

\author{
Ditte Marie Mikkelsen ${ }^{1,2, *}$, Søren Rysgaard ${ }^{1}$, Ronnie Nøhr Glud ${ }^{2,3}$ \\ ${ }^{1}$ Greenland Institute of Natural Resources, Box 570, 3900 Nuuk, Greenland \\ ${ }^{2}$ University of Copenhagen, Marine Biological Laboratory, Strandpromenaden 5, 3000 Helsingør, Denmark \\ ${ }^{3}$ Present address: The Scottish Association for Marine Science, Oban, Argyll PA37 1QA, UK
}

\begin{abstract}
We investigated the microalgal community in sea ice and in the water column of Kobbefjord, West Greenland, through an entire sea ice season. Temporal variation in physical (photosynthetically active radiation [PAR], temperature, brine volume) and chemical (salinity, nutrient concentration) properties confirmed that sea ice is a very dynamic habitat. Nevertheless, a viable sea ice algal community was present throughout the year, with a species succession from flagellate dominance (dinoflagellates and cryptophytes) in December to February, followed by Chaetoceros simplex (a centric diatom) in March and pennate diatoms in May. Sea ice algal composition, biomass and productivity were influenced by PAR and brine volume, with colonization (enhanced by large brine volume) apparent during sea ice melt. Sea ice chlorophyll levels were generally low $\left(<0.5 \mu \mathrm{g} \mathrm{chl} \mathrm{l}^{-1}\right)$, with 2 distinct blooms (maxima of 1.8 and $2.6 \mu \mathrm{g} \mathrm{chl} \mathrm{l}^{-1}$ in March and May, respectively). Primary production mirrored biomass dynamic, which had 2 seasonal peaks of ca. 21 and $15 \mathrm{mg} \mathrm{C} \mathrm{m}^{-2} \mathrm{~d}^{-1}$. Integrated primary production over 7 mo was $0.8 \mathrm{~g} \mathrm{C} \mathrm{m}^{-2}$ in sea ice and $94.4 \mathrm{~g} \mathrm{C} \mathrm{m}^{-2}$ in the water column, with the vast majority of the pelagic production occurring just after sea ice melt (when primary production peaked at $\left.4.2 \mathrm{~g} \mathrm{C} \mathrm{m}^{-2} \mathrm{~d}^{-1}\right)$. There was no conclusive evidence of algal seeding. Sea ice algae contributed $30 \%$ of total (sympagic plus pelagic) primary production during the sea ice season, but less than $1 \%$ annually
\end{abstract}

KEY WORDS: Sea ice $\cdot$ Algae $\cdot$ Arctic $\cdot$ Primary production $\cdot$ Sympagic $\cdot$ Temporal $\cdot$ Flagellates Diatoms

Resale or republication not permitted without written consent of the publisher

\section{INTRODUCTION}

Sea ice environments are highly dynamic and have large variations in temperature, salinity and nutrient availability (Gradinger et al. 1999). Organisms are incorporated during sea ice formation (Gradinger \& Ikävalko 1998) and some are able to survive and even flourish within the 3-dimensional network of brine channels and inclusions. The primary producers of this habitat are diverse; most algal phyla have been reported from sea ice, but pennate diatoms are considered the dominant group (Horner 1985). Most measurements of Arctic sea ice algal primary production range from 5-15 $\mathrm{g} \mathrm{C} \mathrm{m}^{-2} \mathrm{yr}^{-1}$ (Arrigo 2003), but values below $1 \mathrm{~g} \mathrm{C} \mathrm{m}^{-2} \mathrm{yr}^{-1}$ have been reported from coastal fast ice environments (e.g. Rysgaard et al. 2001). The sea ice algal contribution to total annual primary production ranges from $<1 \%$ (Rysgaard et al. 2001) to $66 \%$ (Horner \& Schrader 1982), with marked spatial variation resulting, in part, from differences in the length of the sea ice cover season (Haecky \& Andersson 1999).

In addition to primary production within the ice matrix, sea ice can affect the pelagic spring bloom. Sea ice algae may act as inocula with possible influence on both the species composition and magnitude of the pelagic spring bloom (e.g. Syvertsen 1991). This influence is still subject to debate; for sea ice algae to have 
these effects on the pelagic community, the inocula must be viable, competitive and remain suspended when released into the water column.

Comprehensive long-term studies are needed in order to understand the ecological dynamics of this vast ecosystem, including its contribution to total primary production. Much of the taxonomic research has focused on the lowermost sea ice layer (e.g. Cota et al. 1991), and the complicated and expensive logistical demands of Arctic sea ice research have restricted the number of seasonal studies. This study aims to (1) describe the dynamics of the sea ice microalgal community throughout a season, (2) identify relations between microalgal communities in sea ice and seawater and (3) quantify the contribution of sea ice algae to total (sympagic + pelagic) primary production.

\section{MATERIALS AND METHODS}

Kobbefjord (Danish name), or Kangerluarsunnguaq (Greenlandic Inuktitut name), is a sill fjord near Nuuk, West Greenland (Fig. 1). The fjord is ca. $17 \mathrm{~km}$ long, and 0.8 to $2.0 \mathrm{~km}$ wide. The innermost part of the fjord (depth $\sim 100 \mathrm{~m}$ ) is usually sea ice covered, with extensive interannual variation. This study spans 7 mo from November 27, 2005, prior to sea ice formation, to June 27, 2006, when all sea ice had vanished. Two positions in the fjord were visited approximately every $3 \mathrm{wk}, 1$ on the sea ice $\left(64^{\circ} 09.69^{\prime} \mathrm{N} 51^{\circ} 27.17^{\prime} \mathrm{W}\right)$ and 1 on the seaward-growing or receding floe edge.

At the sea ice station, light intensity (Li-Cor 190SA quantum Q, Li-Cor), air temperature (Testo 110 thermometer) and snow thickness were determined, and sea ice cores were taken using an ice auger (Mark III, Kovacs Enterprises). Sea ice thickness was measured and sea ice temperature profiles were immediately ob-

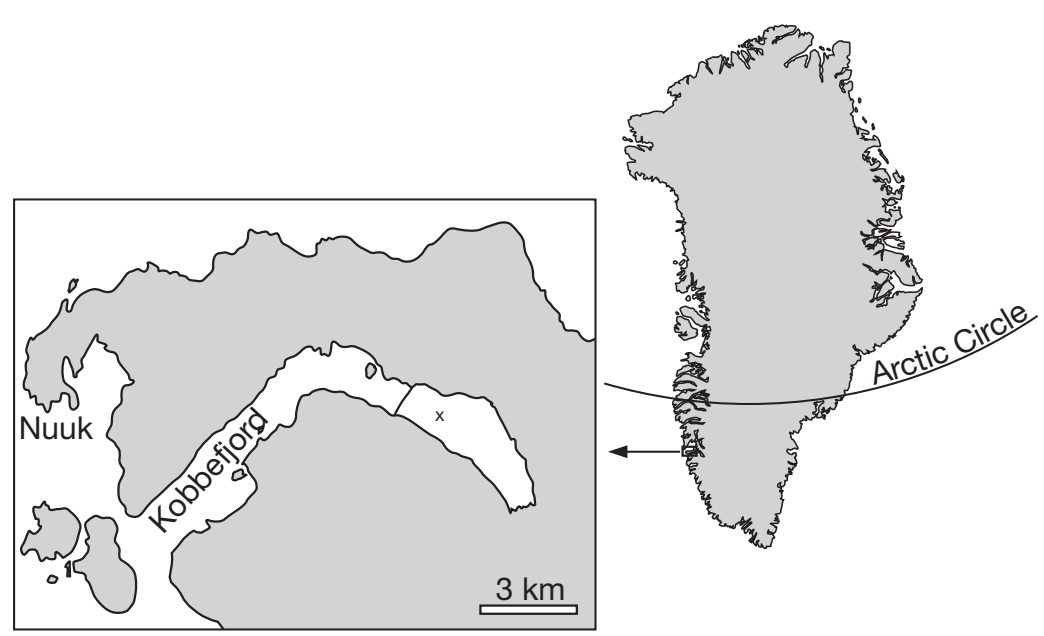

Fig. 1. Kobbefjord/Kangerluarssunguaq, West Greenland. Line marks maximum sea ice extent. $\mathrm{x}$ : sea ice station $\left(64^{\circ} 09.69^{\prime} \mathrm{N}, 51^{\circ} 27.17^{\prime} \mathrm{W}\right)$ tained by drilling a hole (diam. $3 \mathrm{~mm}$ ) and measuring the core temperature (Testo 110 thermometer). Two cores were cut into $10 \mathrm{~cm}$ slices for determination of salinity, algal composition, chlorophyll, and nutrient concentrations (nitrate + nitrite, silicate, phosphate). The lower $10 \mathrm{~cm}$ of 5 cores were obtained for measurement of primary production. Sea ice samples were transported to the laboratory in polyethylene containers, and melted at $10 \mu \mathrm{mol}$ photons $\mathrm{m}^{-2} \mathrm{~s}^{-1}$ at $4{ }^{\circ} \mathrm{C}$, a process that took 2 to $3 \mathrm{~d}$. The photon irradiance levels at which the sea ice was melted were chosen as representative of expected low/minimum irradiance in the sea ice, based on the assumption that the sea ice algae would remain viable but not grow excessively during thawing. An additional ice core was kept frozen for dissolved inorganic carbon (DIC) analysis. Seawater samples for algal composition, primary production, DIC, nutrient and chlorophyll analysis were collected with a Niskin water sampler (KC Denmark) at depths of 1, 5, 10, 15, 25 and $50 \mathrm{~m}$ at the floe edge. CTD-profiles (CTD plus SIS-1000, Sensoren Instrumente Systemen) were obtained on all sampling dates at 1 or both stations.

The conductivity of melted sea ice was measured (Thermo Orion 3-star with Orion 013610MD conductivity cell) and converted to salinity (Grasshoff et al. 1983). Sea ice brine salinity was calculated as a function of temperature (Cox \& Weeks 1983) and brine volume as a function of bulk salinity, density and temperature (Cox \& Weeks 1983, Leppäranta \& Manninen 1988). Seawater and melted sea ice samples were GF/C filtered, and kept frozen $\left(-18^{\circ} \mathrm{C}\right)$ until nutrient analysis. Phosphate $\left(\mathrm{PO}_{4}{ }^{3-}\right)$ concentrations were determined using a standard spectrophotometric approach (Koroleff 1983). Nitrate + nitrite $\left(\mathrm{NO}_{3}{ }^{-}+\mathrm{NO}_{2}{ }^{-}\right)$concentrations were measured by vanadium chloride reduction (Braman \& Hendrix 1989). Silicate $\left(\mathrm{SiO}_{2}\right)$ concentrations were determined by a standard spectrophotometric method (Strickland \& Parsons 1972, Grasshoff et al. 1983). Triplicate measurements were performed on each sample with standard deviations $<0.05 \mu \mathrm{M}\left(\mathrm{PO}_{4}{ }^{3-}\right), 0.5 \mu \mathrm{M}$ $\left(\mathrm{NO}_{\mathrm{x}}\right)$ and $0.2 \mu \mathrm{M}\left(\mathrm{SiO}_{2}\right)$.

Melted sea ice and seawater samples were preserved in Lugol's solution (to a final concentration of $1 \%$ ) for taxonomic analysis. The samples were allowed to settle for minimum $16 \mathrm{~h}$ in 10 or $50 \mathrm{ml}$ chambers before counting algae and protozoa at $200 \times$ magnification. Analyses were performed using an inverted microscope (Leica DM IL) and photo documentation was obtained with a digital microscope camera (Leica DFC280). The identification of species and morphological groups was primarily based on the 
work of Tomas (1997). Melting sea ice directly induces osmotic stress which may cause cell lysis, and different approaches have been taken to mitigate this (e.g. melting the sea ice in ample pre-filtered water (Quillfeldt 1996, Ikävalko 1998)). As the algal sea ice environment undergoes large natural variations in salinity and microhabitat configuration (i.e. brine inclusions), it is likely that sea ice algae have high halotolerance. Melting sea ice directly and slowly at a low temperature, as in this study, also exposes the algae to osmotic stress, but provides an advantage in that all measurements are performed on the same core. Sea ice algae are more tolerant to decreasing salinites than to increasing salinities (Kirst \& Wiencke 1995), and the presence of flagellate cells such as prasinophytes indicates that the sea ice algae in Kobbefjord were capable of coping with the osmotic stress. Sea ice algae were measured (with a Leica IM500), and carbon content was calculated according to equations derived from Menden-Deuer \& Lessard (2000).

Seawater and melted sea ice samples were GF/C filtered (<0.1 bar) for chlorophyll determination. Chlorophyll was extracted in $96 \%$ ethanol for $18 \mathrm{~h}$ (Jespersen \& Christoffersen 1987). Fluorescence was measured (TD-700 fluorometer, Turner Designs) before and after addition of $200 \mu \mathrm{l} 1 \mathrm{M}$ hydrochloric acid. Addition of hydrochloric acid degrades chlorophyll-like pigments (Aminot \& Rey 2000), and the difference between the two measurements is thus total chlorophyll. The fluorometer measurements were calibrated against spectrophotometrically determined chlorophyll content in water samples (Dansk Standardiseringsråd 1986) using a linear regression $\left(\mathrm{r}^{2}=0.99, \mathrm{p}<<0.01, \mathrm{n}=13\right)$.

Primary production was measured in melted bottom sea ice and seawater from a depth of $10 \mathrm{~m}$ at the floe edge using the ${ }^{14} \mathrm{C}$ incubation technique (SteemanNielsen 1952). The samples were incubated in Winkler bottles for $2 \mathrm{~h}$ under constant conditions of $40 \mu \mathrm{mol}$ photons $\mathrm{m}^{-2} \mathrm{~s}^{-1}$ and $4^{\circ} \mathrm{C}$. Though incubation should ideally be performed under in situ conditions of photosynthetically available radiation (PAR), temperature and spectral composition, microalgae are able to quickly adapt to changes in light conditions (Glud et al. 2007), and incubation under known conditions can be extrapolated. However, melting sea ice is likely to have affected the physiological condition of the sea ice algae, and primary production of sea ice is possibly underestimated. Using PerkinElmer Ultima Gold scintillation liquid, the samples were counted with a PerkinElmer TriCarb 2800 TR liquid scintillation analyzer. Dissolved inorganic carbon (DIC) was measured in sea ice (melted in an airtight plastic bag (Hansen et al. 2000) with a CM5012 $\mathrm{CO}_{2}$ coulometer as described by Rysgaard \& Glud (2004). Asiaq (Greenland Survey) supplied hourly irradiance $\left(\mathrm{W} \mathrm{m}^{-2}\right)$, which was con- verted to PAR after calibration $\left(\mathrm{r}^{2}=0.99, \mathrm{p} \ll 0.001\right.$, $\mathrm{n}=133$ ) with a LiCor 1400 quantum meter. Available PAR on each sampling date was calculated at several depths $(5,15,30$ and $45 \mathrm{~cm}$ in sea ice and 5, 15, 25 and $50 \mathrm{~m}$ in seawater) using attenuation coefficients of $0.09 \mathrm{~m}^{-1}$ (seawater), $0.9 \mathrm{~m}^{-1}$ (sea ice) (Roberts et al. 2002) and $4.8 \mathrm{~m}^{-1}$ (snow) (Glud et al. 2007). Primary production was calculated using the measured concentration of DIC. Primary production was corrected for available PAR and chlorophyll concentration assuming linear relations, and integrated for the entire sea ice core/water column. The values were then integrated for the season.

To assess whether temporal variation exceeded horizontal heterogeneity, a sea ice spatial study was conducted in mid-March. Ten sea ice cores were obtained at a distance of $0,10 \mathrm{~cm}, 50 \mathrm{~cm}, 1 \mathrm{~m}, 5 \mathrm{~m}, 10 \mathrm{~m}, 50 \mathrm{~m}$, $100 \mathrm{~m}, 500 \mathrm{~m}$ and $1000 \mathrm{~m}$ from the sea ice station towards the northern shore of the fjord. Sea ice thickness and temperature profiles (Testo 110 thermometer) were measured and the cores were cut into $15 \mathrm{~cm}$ slices for determination of salinity, algal composition, chlorophyll and nutrient concentrations (as above).

To compare species compositions of the sea ice and pelagic algal communities, we used the PRIMER software package (Clarke 1993) to analyze species abundance data. Total abundance was 4 th root-transformed before a similarity matrix based on the Bray-Curtis similarity measure was constructed. The resemblance in species composition between samples was then ordinated using non-metric multidimensional scaling (MDS). In addition, the Shannon-Wiener, Pielou's evenness and ES200 diversity indices were calculated for the sea ice algae.

\section{RESULTS}

\section{Abiotic parameters}

Sea ice (Fig. 2a) grew at ca. $7 \mathrm{~mm} \mathrm{~d}^{-1}$ throughout December and January. The growth rate then slowed, and ice cover remained relatively constant around $55 \mathrm{~cm}$ until the beginning of April. At maximum extent, the sea ice covered ca. $8 \mathrm{~km}^{2}$. The sea ice did not break, but melted in May at a rate of $30 \mathrm{~mm} \mathrm{~d}^{-1}$. The amount of snow (Fig. 2a) covering the sea ice varied during the season, with approximately $15 \mathrm{~cm}$ during winter. In March, the snow was blown away by a storm, followed by a heavy snowfall of $40 \mathrm{~cm}$ in April, which remained until May. Surface PAR over the year fitted a bell-shaped curve, with a mean daily surface value (Fig. 2b) of $60 \mu \mathrm{mol} \mathrm{m} \mathrm{m}^{-2} \mathrm{~s}^{-1}$ in January and $600 \mu \mathrm{mol}$ photons $\mathrm{m}^{-2} \mathrm{~s}^{-1}$ mid-June. Dry snow has a high reflection index and attenuation coefficient, and 

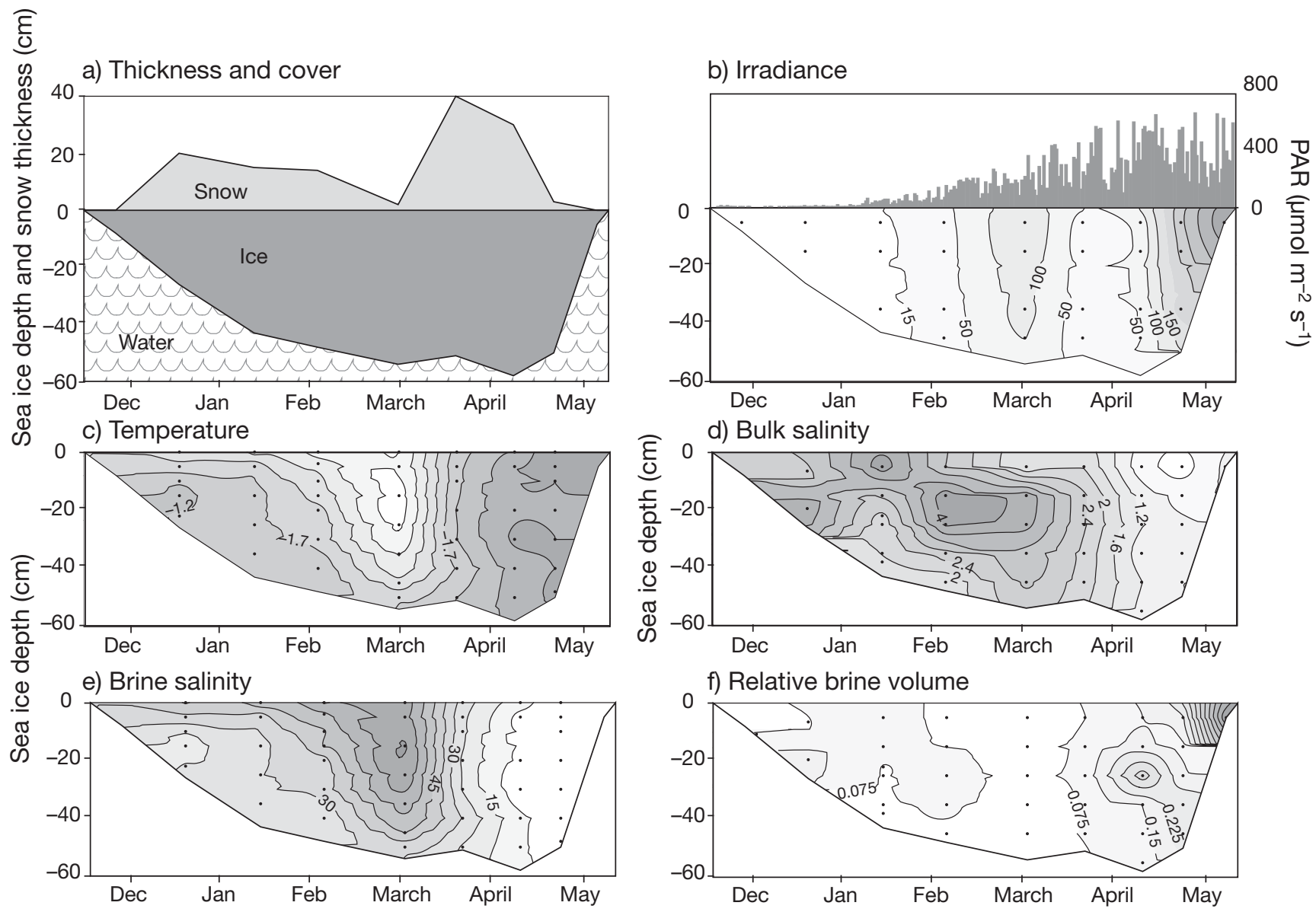

Fig. 2. Sea ice development in Kobbefjord over the season 2005-2006. (a) Sea ice thickness and snow cover (cm), (b) average daily photon irradiance (PAR, $\mu \mathrm{mol} \mathrm{m}{ }^{-2} \mathrm{~s}^{-1}$ ) in sea ice and at surface, (c) temperature $\left({ }^{\circ} \mathrm{C}\right)$, (d) bulk salinity, (e) brine salinity, (f) relative brine volume fraction. The black dots represent duplicate measurements

the snow cover greatly influenced the estimated irradiance within sea ice (Fig. 2b). Photon irradiance throughout the sea ice was very low $\left(<15 \mu \mathrm{mol} \mathrm{m}{ }^{-2} \mathrm{~s}^{-1}\right)$ in winter, increasing to $100 \mu \mathrm{mol} \mathrm{m} \mathrm{m}^{-2} \mathrm{~s}^{-1}$ in March. The snow cover in April attenuated PAR, and when the snow disappeared in May, sea ice photon irradiance increased to $200 \mu \mathrm{mol} \mathrm{m} \mathrm{m}^{-2} \mathrm{~s}^{-1}$. Sea ice reached a minimum temperature of $-4^{\circ} \mathrm{C}$ in March, and then gradually warmed to $0^{\circ} \mathrm{C}$ in late May (Fig 2c). Sea ice bulk salinity (Fig. 2d) varied vertically throughout winter, with lower values in the bottom sea ice. Overall, bulk salinity decreased with sea ice age, resulting in nearly fresh (salinity <1) conditions in May. Brine salinity (Fig. 2e) was calculated from the sea ice temperature and followed an inverse pattern, with a maximum salinity of 70 in March. The relative brine volume (v/v, Fig. 2f) decreased to a minimum of 0.05 in March. The volume increased towards sea ice melt, with a pocket of high brine volume at a depth of 10 to $25 \mathrm{~cm}$ in early May.

During the sea ice season, we observed a weak halocline (salinity change of 0.5 ) and a weak thermocline (temperature change of $0.2^{\circ} \mathrm{C}$ ) ca. $1 \mathrm{~m}$ below sea ice, while the rest of the water column was well mixed. At the onset of sea ice melt, the water column became stratified, with a halocline (salinity change from 32 to 33.2 at $5 \mathrm{~m}$ ) and a gradual thermocline (from $3.2^{\circ} \mathrm{C}$ at $1 \mathrm{~m}$ to $0.5^{\circ} \mathrm{C}$ at $\left.15 \mathrm{~m}\right)$.

Overall, seawater salinity varied from 32 to 33.5 , while temperature varied from $-0.4^{\circ} \mathrm{C}$ to $2^{\circ} \mathrm{C}$ (across all depths).

Nutrient (phosphate, silicate and nitrate+nitrite) concentrations in the sea ice varied temporally and differently by ionic species. The concentration of nitrate+ nitrite (Fig 3a) initially decreased from $2.5 \mu \mathrm{M}$ in December to $<0.5 \mu \mathrm{M}$ in the middle sea ice in March. There was an increase in concentration throughout the sea ice, reaching $4 \mu \mathrm{M}$ in the top sea ice in late April, followed by a decrease to $<1 \mu \mathrm{M}$ during ice melt in May. Phosphate concentration (Fig. 3b) decreased from $0.3 \mu \mathrm{M}$ in December to $\sim 0.15 \mu \mathrm{M}$ throughout the sea ice in February. In March, there was a slight increase to $0.2 \mu \mathrm{M}$ in the upper sea ice, while the 
a) Nitrate + nitrite

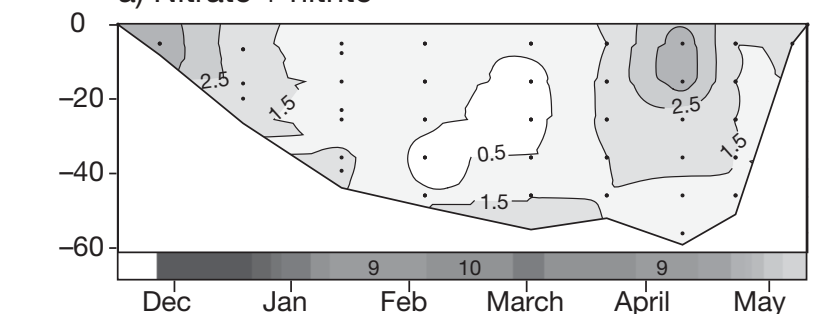

b) Phosphate

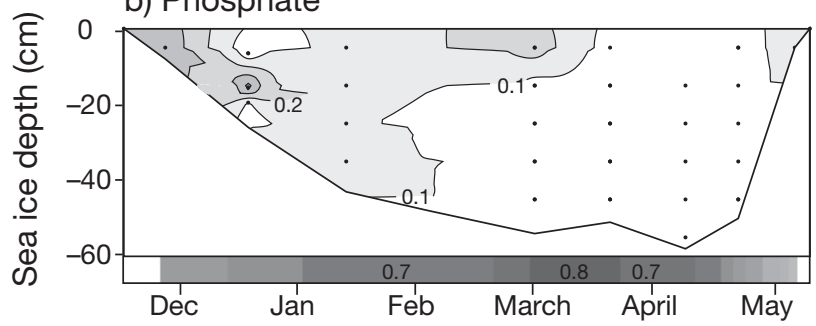

c) Silicate

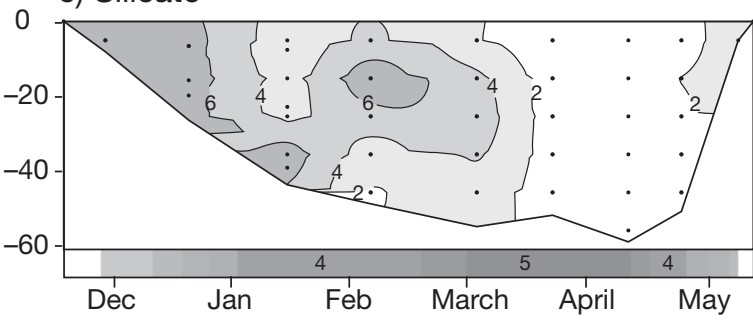

Fig. 3. Nutrient concentrations $(\mu \mathrm{M})$ in bulk sea ice (contour lines) and seawater (bar). (a) $\mathrm{NO}_{\mathrm{x}}$ (nitrate + nitrite), (b) phosphate, (c) silicate. The black dots represent duplicate measurements

remainder of the sea ice had concentrations $<0.1 \mu \mathrm{M}$. The phosphate concentration in the upper sea ice decreased in April, and the entire sea ice contained $<0.1 \mu \mathrm{M}$ until sea ice melt, when there was an increase to $0.14 \mu \mathrm{M}$. Silicate concentrations (Fig. 3c) varied from 4 to $6.5 \mu \mathrm{M}$ in winter. In March, the concentration decreased, reaching minimum concentrations $(<1 \mu \mathrm{M})$ in April. In May, the concentration increased to $2 \mu \mathrm{M}$. Silicate concentrations were correlated with salinity $\left(\mathrm{r}^{2}=0.66, \mathrm{p}<0.001, \mathrm{n}=28\right)$ until March $\left(\mathrm{r}^{2}=0.00, \mathrm{p}<\right.$ $0.1, \mathrm{n}=26$ ), suggesting little biological influence in winter. Nitrate + nitrite and phosphate concentrations showed no consistent correlation pattern.

Throughout the sea ice cover season, there was little vertical variation in seawater nutrient concentrations in the upper $50 \mathrm{~m}$ of the water column. Initial seawater concentrations (at the time of sea ice formation) of nitrate + nitrite, phosphate and silicate were 13, 0.5 and $3 \mu \mathrm{M}$, respectively (Fig. 3, bars). During the sea ice season, the concentration of nitrate + nitrite remained varied from 9 to $11 \mu \mathrm{M}$, while the concentration of phosphate and silicate varied from 0.7 to $0.9 \mu \mathrm{M}$ and 4 to $6 \mu \mathrm{M}$, respectively. All nutrient concentrations decreased during sea ice thaw in May.

\section{Biotic parameters}

Algae were present in the sea ice throughout the season. Small $(\sim 5 \mu \mathrm{m})$ unidentified flagellates (Fig. 4a), Prasinophyceae (Fig. 4b), Dinophyceae (Fig. 4c), Cryptophyceae (Fig. 4d) and Bacillariophyceae (both centric, particularly Chaetoceros simplex [Fig. 4e], and pennate [Fig. 4f]) were regular components of the sea ice algal community. In addition, Dictyochophyceae (Dictyocha speculum), Haptophyta (Chrysochromulina spp.), Chrysophyceae, Euglenophyceae (e.g. Eutreptiella spp.), Raphidophyceae and Chlorophyceae occurred in low numbers. Initially, most taxa were represented in the sea ice, resulting in high ES200 and Shannon-Wiener diversity indices (Fig. 5a). Index values decreased (due to lysis, grazing, release to water column, etc.) to a minimum in March, followed by an increase towards sea ice melt in May. Pielou's evenness index was less pronounced, but also showed a drop in March. Based on dominance (the relative numerical contribution of one group), 3 assemblages are recognized: flagellates in January/February, the centric diatom Chaetoceros simplex midMarch and pennate diatoms in May. The flagellates in winter were gymnodinoid dinoflagellates (e.g. Gymnodinium spp.), cryptophytes (particularly Rhodomonas), prasinophytes (Pyramimonas spp.) and small ( 5 $\mu \mathrm{m})$ unidentified flagellates. All flagellate groups remained in the sea ice throughout the season, but became of less numerical importance. Only 2 diatom species were observed in winter, both rarely and in low abundance $(<1 \%)$. In March, one of these species (Chaetoceros simplex) bloomed and became dominant, contributing up to $75 \%$ of the total sea ice algal abundance. During April, C. simplex was of reduced numerical importance $(\sim 15 \%)$ as several new genera of pennate diatoms (Navicula, Nitzschia) appeared, and cryptophyte and small $(\sim 5 \mu \mathrm{m})$ flagellate abundance increased. Dinoflagellate cysts occurred concurrently with a decrease in dinoflagellates, particularly in the lower parts of the sea ice. During sea ice melt in May, the pennate diatoms became numerically dominant (>70\%).

Converting cell numbers into biomass by applying the equations of Menden-Deuer \& Lessard (2000) did not change the overall succession pattern, but shifted the relative contributions of the respective taxonomic groups as well as the integrated annual importance. This was particularly true for small cells that were present in high numbers, but had small cell volumes and low carbon contents. When calculations were based on algal cell carbon instead of algal cell density, the integrated annual contribution of the small $(\sim 5 \mu \mathrm{m})$ unidentified flagellates decreased (14 to $1 \%$ ), as did the contribution of Chaetoceros simplex (27 to $20 \%$ ). Concurrently, the integrated annual contribution for other 
a) Small unidentified flagellates

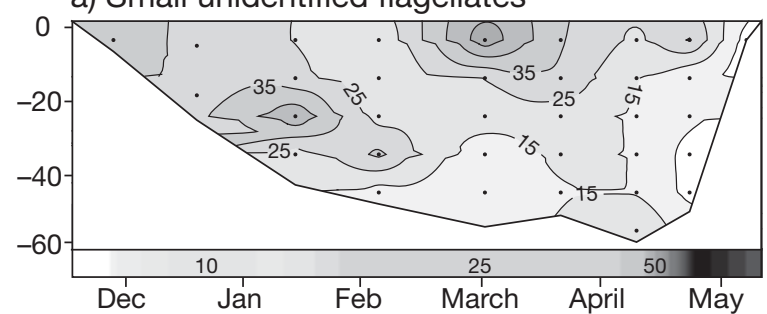

c) Dinoflagellates

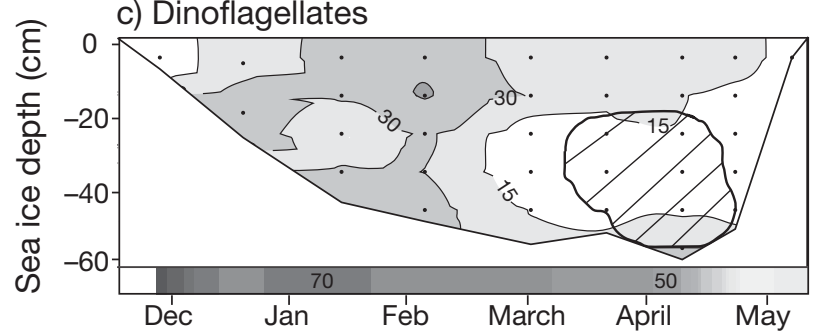

e) Chaetoceros simplex

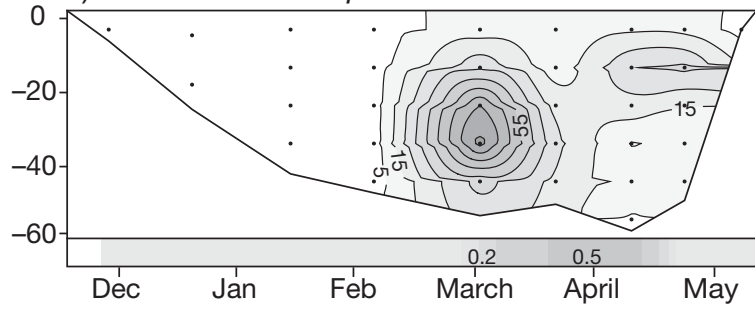

b) Prasinophytes

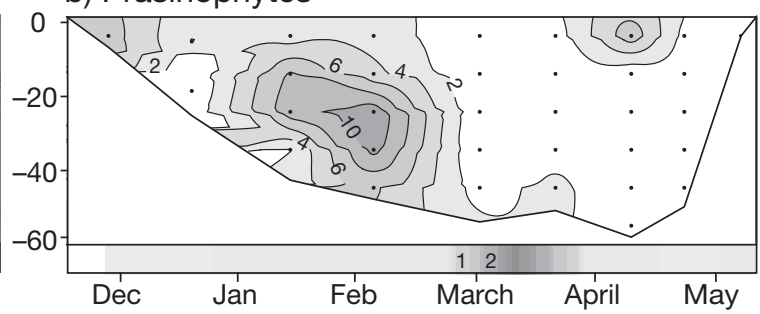

d) Cryptophytes

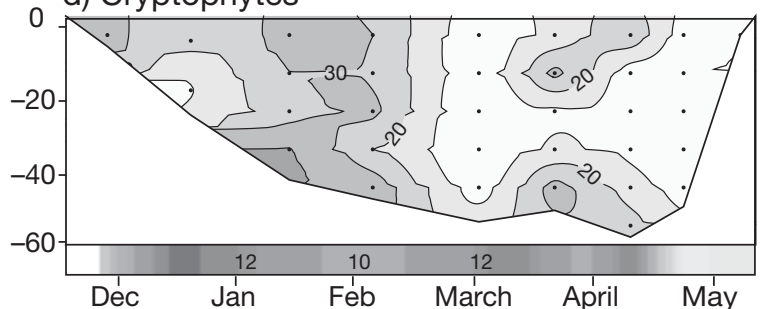

f) Pennate diatoms

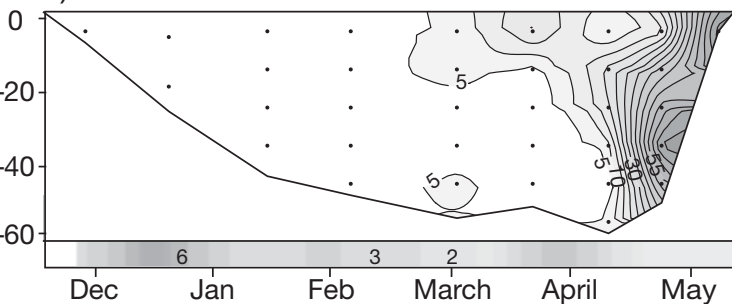

Fig. 4. Contribution of algal phyla (\%, based on cells $\mathrm{l}^{-1}$ ) to sea ice (contour lines) and pelagic (bar) microalgal community. (a) Small $(\sim 5 \mu \mathrm{m})$ unidentified flagellates; (b) prasinophytes; (c) dinoflagellates, the hatched area indicates presence (>10\%) of dinoflagellate cysts; (d) Cryptophytes; (e) Chaetoceros simplex, a small centric diatom; (f) pennate diatoms. The black dots represent duplicate measurements
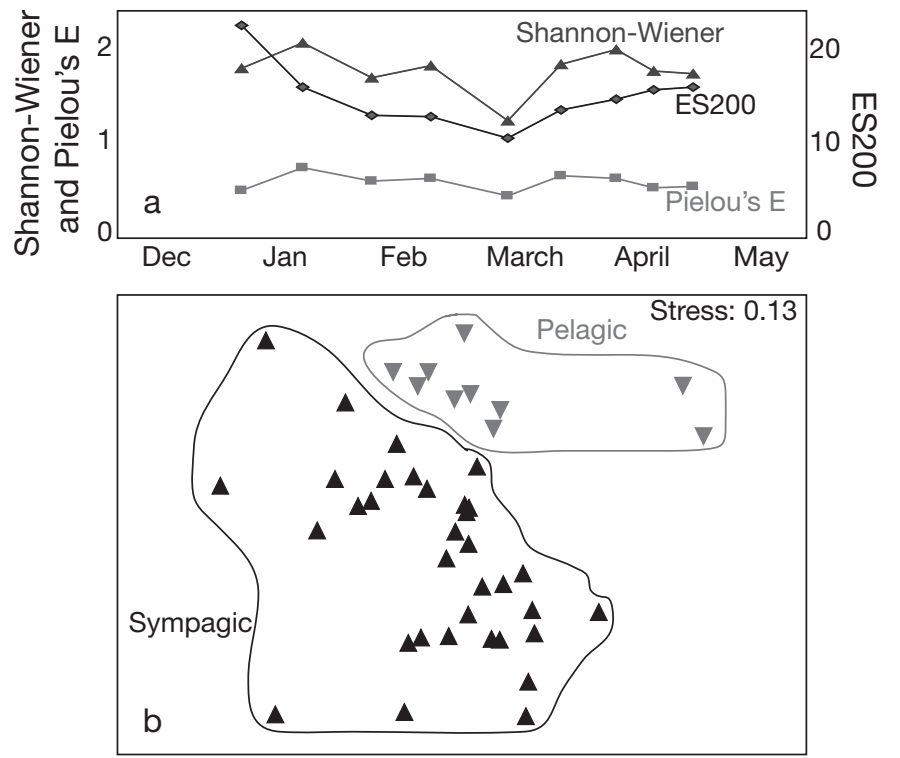

Fig. 5. (a) Diversity indices in sea ice (Pielou's E: Pielou's evenness index), and (b) MDS ordination of all algal samples showing separation of pelagic and sympagic groups groups increased, particularly for pennate diatoms (25 to $42 \%$ ).

The MDS ordination (Fig. 5b) showed that the sea ice and pelagic algal assemblages fell into separate groupings. Sixteen percent of the dissimilarity between these groups was due to Chaetoceros simplex, small flagellates and Rhodomonas sp. The pelagic algal community in the upper $50 \mathrm{~m}$ of the water column (Fig. 4, bars) consisted primarily of dinoflagellates (Gymnodinium spp.) during the sea ice season (>60\%), with dinoflagellates cysts observed in small numbers in late April. Pennate diatoms were present in the seawater throughout the season (1 to $7 \%$ ). An increase in prasinophytes (0 to $2 \%$ ) occurred in February. Centric diatoms were virtually absent in seawater during sea ice cover, with the exception of a small increase in the abundance of Chaetoceros simplex in March. Initially, small $(\sim 5 \mu \mathrm{m})$ unidentified flagellates contributed merely $1.5 \%$. During the sea ice season, they became abundant, contributing 10 to $35 \%$ until sea ice melt (late May) when they dominated numerically (99\%). At this time, several species of Chaetoceros (including, but not restricted to $C$. simplex) and Thalassiosira appeared. 
a) Chlorophyll

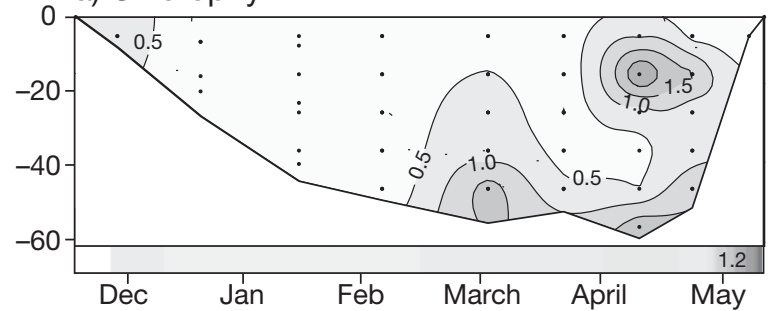

b) Autotrophic cells

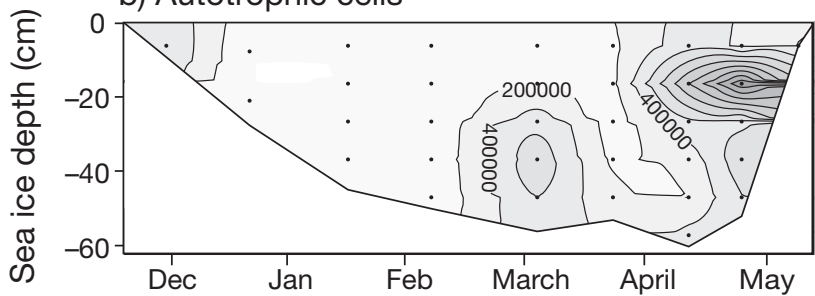

c) Carbon concentration

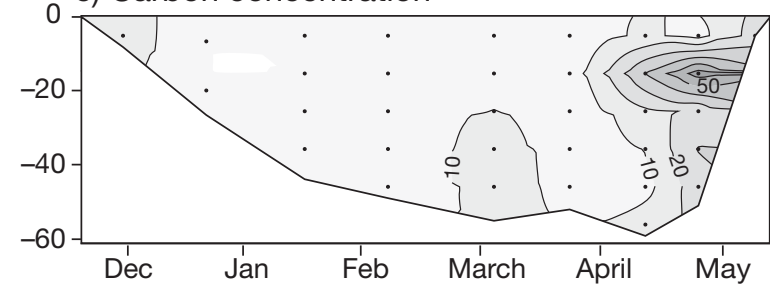

Fig. 6. (a) Chlorophyll concentrations ( $\mu \mathrm{g} \mathrm{chl} \mathrm{l}^{-1}$ ) in sea ice (contour lines) and in the water column (bar). (b) Densities of autotrophic cells (cells $\mathrm{l}^{-1}$ ) in sea ice. (c) Carbon concentration $\left(\mu \mathrm{g} \mathrm{Cl}^{-1}\right)$ in sea ice. The black dots represent duplicate measurements

Sea ice chlorophyll levels (Fig. 6a) were low $\left(<0.5 \mu \mathrm{g} \mathrm{chl}^{-1}\right)$ throughout winter. In March, a bottom

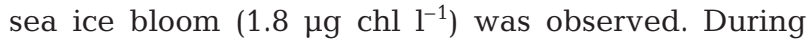
April and May, a widespread bloom was present, reaching a maximum of $2.6 \mu \mathrm{g} \mathrm{chl} \mathrm{l}^{-1}$. Algal cell densities in sea ice (Fig. 6b) were positively related to chlorophyll $\left(\mathrm{r}^{2}=0.5, \mathrm{p}<0.01, \mathrm{n}=33\right)$, and tracked a similar pattern, with a bottom sea ice bloom in March

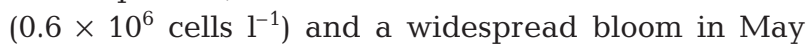

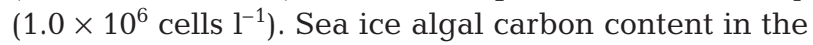
bottom sea ice (Fig. 6c) also peaked in March $(\sim 10 \mu \mathrm{g}$ $\left.\mathrm{C}^{-1}\right)$ and in May $\left(\sim 60 \mu \mathrm{g} \mathrm{C} \mathrm{l}^{-1}\right)$. In the seawater, chlorophyll concentrations were negligible $(<0.05 \mu \mathrm{g}$ chl $\mathrm{l}^{-1}$ ) until late May when a bloom occurred. The

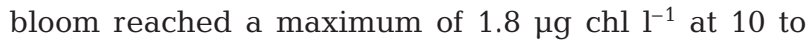
$15 \mathrm{~m}$, after which chlorophyll decreased to $1.2 \mu \mathrm{g}$ chl $1^{-1}$ mid-June.

Sea ice primary production (integrated by sea ice core, Fig. 7a, and as relative contribution, Fig. 7b) showed two distinct peaks of similar magnitude in March (21 $\mathrm{mg} \mathrm{C} \mathrm{m}^{-2} \mathrm{~d}^{-1}$ ) and May (15 mg C m ${ }^{-2} \mathrm{~d}^{-1}$ ). Before and between the peaks, production was low. Annual sea ice primary production was $0.78 \mathrm{~g} \mathrm{C} \mathrm{m}^{-2}$.

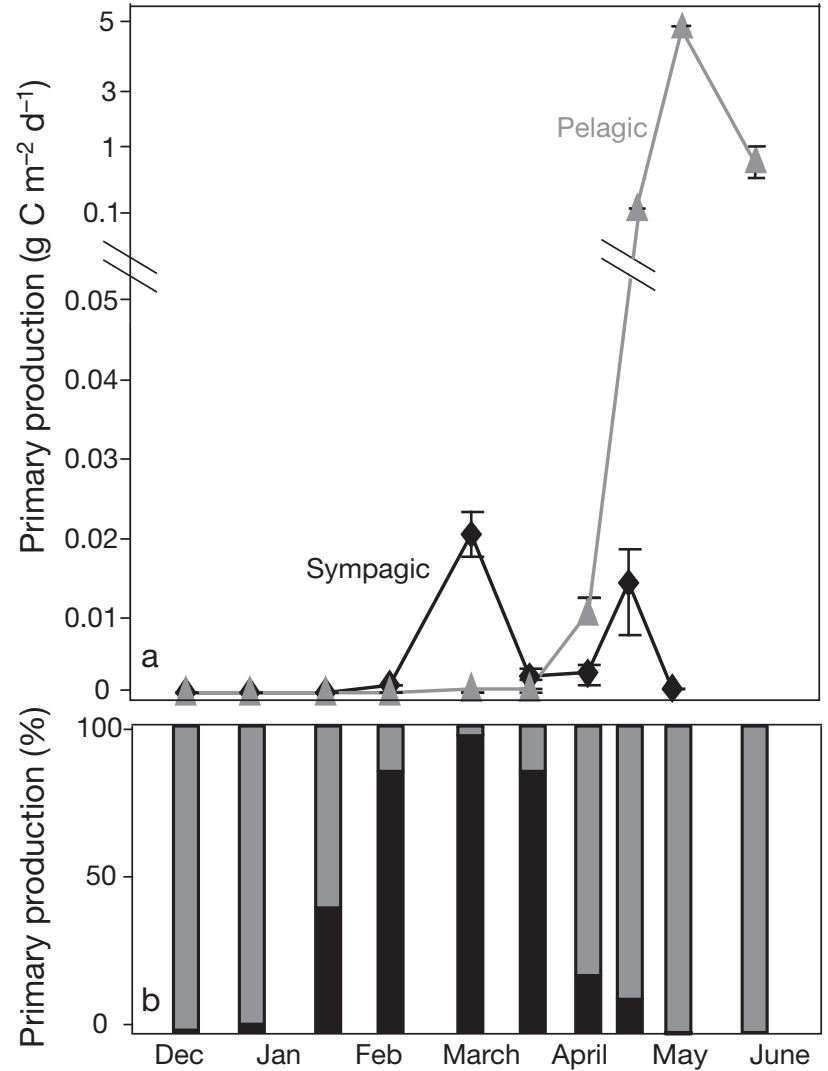

Fig. 7. (a) Primary production $\left(\mathrm{g} \mathrm{C} \mathrm{m}^{-2} \mathrm{~d}^{-1}\right)$ in sea ice (sympagic) and seawater (pelagic); bars are ranges (minimum and maximum). (b) Relative contributions (\%) of sympagic and pelagic algae to primary production

Primary production in seawater was negligible until sea ice melt (late May), when a large peak $\left(4.2 \mathrm{~g} \mathrm{C} \mathrm{m}^{-2}\right.$ $\mathrm{d}^{-1}$ ) occurred. By mid-June, pelagic primary production had decreased to $0.7 \mathrm{~g} \mathrm{C} \mathrm{m}^{-2} \mathrm{~d}^{-1}$. Total pelagic production during the stable sea ice cover period was low (ca. $1.8 \mathrm{~g} \mathrm{C} \mathrm{m}^{-2}$ ). If only the season with stable sea ice cover is considered, the contribution of sea ice algae was $30 \%$. However, including the large bloom at sea ice melt time and the ensuing pelagic primary production (i.e. the entire $7 \mathrm{mo}$ ), total pelagic primary production in the upper $50 \mathrm{~m}$ of the water column was $94.4 \mathrm{~g} \mathrm{C} \mathrm{m}^{-2}$. The contribution of sea ice algae to total (pelagic + sympagic) primary production was thus a mere $0.8 \%$ over 7 mo.

\section{Heterogeneity}

Sea ice thicknesses ranged from 52 to $67 \mathrm{~cm}$ along the $1000 \mathrm{~m}$ transect. Parameters varied, with average sea ice core values of 1.8 to 3.6 (bulk salinity), 0.4 to $1.2 \mu \mathrm{g} \mathrm{l}^{-1}$ chlorophyll, 0.05 to $0.2 \mu \mathrm{M}$ phosphate, 3.2 to $6.1 \mu \mathrm{M}$ silicate and temperatures of -3.3 to $-2.4^{\circ} \mathrm{C}$. 
Taxonomic composition was not investigated in detail, but all sea ice cores were dominated by Chaetoceros simplex. To assess sea ice variability, data from the temporal $(7 \mathrm{mo})$ and horizontal (March) study were combined for a 3-way ANOVA with the independent variables of depth, time and distance. Data were not transformed, and ANOVA assumptions were met. The assumption for this analysis is that the measured horizontal variation mid-March is not significantly different from variation at other times during the season. The analysis showed that there was a significant effect $(p<0.01)$ of time on chlorophyll $\left(F_{7,49}=9.0\right)$, temperature $\left(F_{6,24}=66.4\right)$, salinity $\left(F_{6,27}=11.4\right)$, phosphate $\left(F_{6,39}=6.5\right)$ and silicate $\left(F_{7,49}=33.0\right)$. There was also a significant effect ( $\mathrm{p}<0.01$ ) of depth on chlorophyll $\left(F_{13,49}=7.8\right)$, temperature $\left(F_{40,24}=6.8\right)$, salinity $\left(F_{13,27}=2.8\right)$, phosphate $\left(F_{12,39}=4.2\right)$ and silicate $\left(F_{11,49}=6.5\right)$. The interaction between depth and time was significant for chlorophyll, temperature and silicate $(F<4, \mathrm{p}<0.01)$, but not salinity and phosphate $(F<2, \mathrm{p}>0.3)$. For distance, there was a significant effect on phosphate and silicate $(\mathrm{p}<0.05)$, but not on chlorophyll, temperature and salinity ( $p>0.05)$.

\section{DISCUSSION}

Algae were present in sea ice throughout the season, and the community followed a distinct succession with dominance of different taxonomic groups at different times. Pennate diatoms were observed only late in the season, while flagellates and the centric diatom Chaetoceros simplex were dominant in winter and spring, respectively. Though great spatial variation can be found within sea ice (e.g. Rysgaard et al. 2001), the temporal variation in Kobbefjord was, except for phosphate and silicate, not due to sea ice heterogeneity; most of the temporal variation was within the algal assemblage.

The changes in sea ice algal composition in Kobbefjord were related to PAR and brine volume. The influences of brine volume are manifold, with both direct physical constraints (e.g. available habitat) and indirect changes in abiotic conditions (e.g. nutrient concentrations). Previous studies have shown that colonisation of sea ice largely depends on brine volume (Krembs et al. 2000), and the seasonal changes in brine volume likely influence both the succession within the sympagic algal community and colonization by pelagic algae. In April and May in Kobbefjord, the thawinduced increased brine volume allowed percolation processes and direct exchange of organisms between sea ice and seawater. No new species of pennate diatoms had been observed previously in the sea ice, and their appearance documents an outside influence on the sea ice algal community. The appearance of cytoplasts indicated that pennate diatoms were not thriving, and whether they actively colonize the sea ice is not known.

The importance of PAR on species composition is indicated by flagellate dominance under low light (winter, and the period with heavy snow cover), while diatoms dominated during periods of increased PAR (March and May). It is likely that the sea ice flagellates supplemented or substituted photosynthesis with mixotrophy or heterotrophy. A species of Rhodomonas (the dominant sea ice cryptophyte genus) has been identified as a likely mixotroph (Hammer et al. 2002), and hetero- and mixotrophy is common among dinoflagellates (Arrigo 2003). However, pennate diatoms are also nutritionally diverse (e.g. Horner 1985), and their absence during winter and spring is a subject for further studies.

A further factor known to influence the development of sea ice algal communities is grazing (Gradinger et al. 1999), but we have no means to evaluate this aspect. Ciliates (e.g. Philasterine sp., Holophrya simplex) were present throughout the season, and decreased in abundance at sea ice melt (data not shown).

Dinoflagellate cysts were observed in sea ice in April, but were only found scattered in the seawater. The absence of an increase in pelagic and sympagic dinoflagellates coupled with the spiny structure of the cysts (they were observed to cluster) indicates that the cysts were exported to deeper waters. Cysts are resistant stages that survive temporally harsh environmental conditions, and subsequently excyst (Stoecker et al. 1997); it is likely that the cysts bloomed later in the season or 'over-summered' to excyst when incorporated into sea ice the following season.

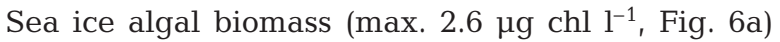
was low, but similar to previously reported values (e.g. Horner \& Schrader 1982). The presence of a chlorophyll maximum within the sea ice in April/May emphasizes the need for studies of the entire sea ice core, not only the bottom sea ice.

There is usually a spring peak in sea ice primary productivity as light levels increase, followed by a decrease due to e.g. nutrient limitation (Haecky \& Andersson 1999). Sympagic primary production (integrated through the sea ice cores) in Kobbefjord was correlated to irradiance $\left(\mathrm{r}^{2}=0.66, \mathrm{p}<0.05, \mathrm{n}=8\right)$, and followed a different pattern with 2 distinct peaks of similar magnitude in March and May, concurrent with the irradiance maxima.

Algae are generally assumed to require nutrients in a ratio of $106 \mathrm{C}: 16 \mathrm{~N}: 15 \mathrm{Si}: 1 \mathrm{P}$, the so-called Redfield ratio amended to include a diatom requirement for silicate (Parsons et al. 1961). Based on this assumption, nitrogen was limiting sea ice algal growth in March 
(N:P of 4) and late May (N:P of 10), while silicate was a limiting factor in late April (Si:P of 7), a time when pennate diatoms began to appear. The observed increases in nitrogen and silicate concentrations in April and May, respectively, may be due to remineralisation within the sea ice and/or exchange with the seawater. Another possibility is that heavy snow cover depressed the sea ice, causing surface flooding and subsequent inflow of nutrients to the sea ice.

The annual sympagic primary production of $0.78 \mathrm{~g} \mathrm{C}$ $\mathrm{m}^{-2}$ in Kobbefjord is comparable to measurements in Young Sound fjord on the northeastern Greenland coast (Rysgaard et al. 2001), and to measurements further offshore in the Greenland Sea (Gradinger et al. 1999, Mock \& Gradinger 1999). Gradinger (1999) suggested that biomass in pack ice is much lower than in fast-ice areas due to the lower nutrient supply, different physical constraints (ice temperature, brine salinity, radiation) or biological interactions (grazing and growth rates). However, the sea ice algal biomasses in Young Sound and Kobbefjord are lower than in other coastal fast-ice areas with similar latitudes, sea ice and snow thicknesses, irradiances and nutrient concentrations (Cota et al. 1991). A possible explanation for the relatively low sea ice primary production and biomass in Greenlandic fjords is greater homogeneity of snow and ice cover (which attenuate light) than in offshore regions where snow cover is much more variable and where cracks in the sea ice or floe edges allow enhanced light penetration and, consequently, elevated primary production (Glud et al. 2007). Another explanation may be related to differences in the initial algal colonization of sea ice in Greenlandic fjords and other Arctic regions. However, more work is needed to resolve this issue.

Pelagic algal biomass and primary production were negligible during the sea ice season, presumably due to PAR limitation. When PAR increased at sea ice melt, a bloom occurred. Short-lived pelagic blooms near the sea ice edge are common, and are attributed to a combination of light availability, water stratification (Heide-Jørgensen et al. 2007) and possibly seeding by sea ice algae (Syvertsen 1991). The peak in pelagic primary production and biomass was followed by a decrease that was concurrent with a tripling in zooplankton cell density (data not shown), indicating that grazing is likely of importance in controlling the pelagic microalgal biomass in Kobbefjord, as is the case in other Greenlandic fjords (Rysgaard et al. 1999). The pelagic bloom in Kobbefjord consisted mainly of small flagellates, which were already present in both sea ice and seawater. Several species that had not previously been observed (Thalassiosira spp. and Chaetoceros spp.) also contributed to the bloom. Though there were indications that some sea ice algae (prasino- phytes, C. simplex) remained suspended and viable when released from the sea ice (Fig. 4b,e), multivariate analysis (Fig. 5) showed that the sympagic and pelagic community were 2 separate entities. The fact that the last two pelagic sampling dates (post sea ice melt) were outliers indicates that the pelagic winter and the sympagic community were connected and that the pelagic summer community was influenced by pelagic species, rather than being seeded from the sea ice.

In Kobbefjord, sympagic primary production of $0.78 \mathrm{~g} \mathrm{C} \mathrm{m}^{-2}$ contributed $0.8 \%$ to the total (sympagic + pelagic) primary production. Though the sympagic primary production may be an underestimate, sea ice primary production is not a major contributor on an annual basis. However, sea ice algae are important primary producers during the season of stable sea ice cover, when pelagic primary production is low.

Acknowledgements. We thank A. Haxen for DIC analysis. Asiaq (Greenland Survey) is acknowledged for providing irradiance data. M. Sejr and N. Risgaard-Petersen are thanked for statistical assistance. Comments by 4 anonymous reviewers are gratefully acknowledged. S.R. and R.N.G. were supported by the Danish National Research Council and DANCEA, the Danish Cooperation for Environment in the Arctic, Danish Ministry of Environment and the Aage V. Jensen Charity Foundation. This work is a contribution to the Zackenberg Basic and Nuuk Basic programmes in Greenland.

\section{LITERATURE CITED}

Aminot A, Rey F (2000) Standard procedure for the determination of chlorophyll $a$ by spectroscopic methods. ICES techniques in marine environmental sciences. ICES, Copenhagen, p 17. Available at: www.ices.dk/ocean/ procedures/timeschl.pdf

Arrigo KR (2003) Primary production in sea ice. In: Thomas DN, Dieckmann G (eds) Sea ice-an introduction to its physics, chemistry, biology and ecology. Blackwell Science, Oxford, p 143-184

$>$ Braman RS, Hendrix SA (1989) Nanogram nitrite and nitrate determination in environmental and biological materials by vanadium(III) reduction with chemiluminescense detection. Anal Chem 61:2715-2718

> Clarke KR (1993) Non-parametric multivariate analyses of changes in community structure. Aust J Ecol 18:117-143

Cota G, Legendre L, Gosselin M, Ingram R (1991) Ecology of bottom ice algae: I. Environmental controls and variability. J Mar Syst 2:257-277

Cox GFN, Weeks WF (1983) Equations for determining the gas and brine volumes in sea-ice samples. J Glaciol 29: 306-316

Dansk Standardiseringsråd (1986) Vandundersøgelse-klorofyl a. Spektrofotometrisk måling i ethanolekstrakt. Copenhagen

Glud RN, Rysgaard S, Kühl M, Hansen JW (2007) The sea-ice in Young Sound: implications for C cycling. In: Rysgaard S, Glud RN (eds) Arctic carbon cycling: a case study from Young Sound. Meddr Grønland, Bioscience 58:62-85

Gradinger R, Ikävalko J (1998) Organism incorporation into 
newly forming Arctic sea ice in the Greenland Sea. J Plankton Res 20:871-886

Gradinger R, Friedrich C, Spindler M (1999) Abundance, biomass and composition of the sea ice biota of the Greenland Sea pack ice. Deep-Sea Res Part II 46:1457-1472

Grasshoff K, Erhardt M, Kremling K (eds) (1983) Methods of seawater analysis. Verlag Chemie, Weinheim

Haecky P, Andersson A (1999) Primary and bacterial production in sea ice in the northern Baltic Sea. Aquat Microb Ecol 20:107-118

Hansen JW, Thamdrup B, Jørgensen BB (2000) Anoxic incubation of sediment in gas-tight plastic bags: a method for biogeochemical process studies. Mar Ecol Prog Ser 208: 273-282

Hammer A, Schumann R, Schubert H (2002) Light and temperature acclimation of Rhodomonas salina (Cryptophyceae): photosynthetic performance. Aquat Microb Ecol 29:287-296

Heide-Jørgensen MP, Lairdre KL, Logsdon ML, Nielsen TG (2007) Springtime coupling between chlorophyll $a$, sea ice and sea surface temperature in Disko Bay, West Greenland. Prog Oceanogr 73:79-95

Horner R (1985) Taxonomy of sea ice microalgae. In: Horner R (ed) Sea ice biota. CRC Press, Boca Raton, FL, p 147-159

Horner R, Schrader GC (1982) Relative contributions of ice algae, phytoplankton and benthic microalgae to primary production in nearshore regions of the Beaufort Sea. Arctic 35:485-503

Ikävalko J (1998) Further observations on flagellates within sea ice in northern Bothnian Bay, the Baltic Sea. Polar Biol 19:323-329

Jespersen AM, Christoffersen K (1987) Measurements of chlorophyll a from phytoplankton using ethanol as extraction solvent. Arch Hydrobiol 109:445-454

Kirst GO, Wiencke C (1995) Ecophysiology of polar algae. J Phycol 31:181-199

Koroleff (1983) Determination of phosphorus. In: Grasshoff K, Erhardt M, Kremling K (eds) Methods of seawater analysis. Verlag Chemie, Weinheim, p 125-139

Krembs C, Gradinger R, Spindler M (2000) Implications of brine channel geometry and surface area for the interaction of sympagic organisms in Arctic sea ice. J Exp Mar Biol Ecol 243:55-80

Leppäranta M, Manninen T (1988) The brine and gas con-

Initial editorial responsibility: Howard Browman, Storebø, Norway; Final editorial responsibility: Hans Heinrich Janssen, Oldendorf/Luhe, Germany tent of sea ice with attention to low salinities and high temperatures. Internal Rep 88-2, Finnish Inst Mar Res, Helsinki

Menden-Deuer S, Lessard EJ (2000) Carbon to volume relationships for dinoflagellates, diatoms and other protist plankton. Limnol Oceanogr 45:569-579

Mock T, Gradinger R (1999) Determination of Arctic ice algal production with a new in situ incubation technique. Mar Ecol Prog Ser 177:15-26

Parsons TR, Stevens K, Strickland JDH (1961) On the chemical composition of eleven species of marine phytoplankton. J Fish Res Board Can 18:1001-1016

Quillfeldt CH (1996) Ice algae and phytoplankton in North Norwegian waters and Arctic waters: species composition, succession and distribution. Doctor Scientiarium thesis, University of Tromsø, Tromsø

Roberts DR, Kühl M, Glud RN, Rysgaard S (2002) Primary production of crustose coralline red algae in a high Arctic Fjord. J Phycol 38:273-283

Rysgaard S, Glud RN (2004) Anaerobic $\mathrm{N}_{2}$ production in Arctic sea ice. Limnol Oceanogr 49:86-94

> Rysgaard S, Nielsen TG, Hansen BW (1999) Seasonal variation in nutrients, pelagic primary production and grazing in a high-Arctic coastal marine ecosystem, Young Sound, Northeast Greenland. Mar Ecol Prog Ser 179:13-25

Rysgaard S, Kühl M, Glud RN, Hansen JW (2001) Biomass, production and horizontal patchiness of sea ice algae in a high-Arctic fjord (Young Sound, NE Greenland). Mar Ecol Prog Ser 223:15-26

Steeman-Nielsen E (1952) The use of radio-active carbon (14C) for measuring organic production in the sea. J Cons 18:117-140

Stoecker DK, Gustafson DE, Merrell JR, Black MMD, Baier CT (1997) Excystment and growth of chrysophytes and dinoflagellates at low temperatures and high salinities in Antarctic sea-ice. J Phycol 33:585-595

Strickland JDH, Parsons TR (1972) A practical handbook of seawater analysis. Fisheries Research Board of Canada, Ottawa

Syvertsen EE (1991) Ice algae in the Barents Sea: types of assemblages, origin, fate and role in the ice-edge phytoplankton bloom. Polar Res 10:277-287

Tomas CR (1997) Identifying marine phytoplankton. Academic Press, San Diego, CA

Submitted: October 16, 2007; Accepted: June 26, 2008

Proofs received from author(s): September 9, 2008 